\title{
Have Gun Laws Changed Since Newtown?
}

\author{
AnnaClare C. Smith ${ }^{\mathrm{a}}$, Anna M. Van Kula ${ }^{\mathrm{a}}$, Greer M. Howard ${ }^{\mathrm{a}}$, and Paul M. Sommers ${ }^{\mathrm{a}}$
}

Using data issued by the Brady Campaign to Prevent Gun Violence, the authors examine the strength of statewide firearm laws across the United States one year before and after the 2012 school shooting in Newtown, Connecticut. Regressions fitted to the cross-section of all states in 2011 and 2013 show how Brady Scores differ across census divisions after allowing for statewide differences in firearm death rates and political party control of the state legislature. In the aftermath of Newtown, gun laws have either not changed or in census divisions where they have significantly changed, they have become less restrictive.

Keywords: Gun control laws; t-tests; regression

\section{Introduction}

Every two years the Brady Campaign to Prevent Gun Violence issues a 100-point scorecard that assigns a numerical value (hereafter, the Brady Score) to each state based on the strength of its firearm laws. Regulations such as background checks on all gun sales (including gun show sales), permit-topurchase requirements on guns and ammunition, and retention of sales records influence a state's Brady Score. The higher a state's Brady Score, the more restrictive that state's laws relating to firearm purchase and ownership. On the 2011 scorecard, Brady Scores ranged from a low of zero (for the states of Alaska, Arizona, and Utah) to a high of 81 (in California). A year after the 2012 shooting that killed 20 children and six adults at Sandy Hook Elementary School in Newtown, Connecticut, another Brady scorecard was issued. The purpose of this paper is to assess what (if any) changes were enacted by states between 2011 and 2013 to make their respective gun laws more restrictive in the aftermath of Newtown.

\section{Methodology}

All 50 states are divided into 9 census divisions: (1) New England, (2) Middle Atlantic, (3) East North Central, (4) West North Central, (5) South Atlantic, (6) East South Central, (7) West South Central, (8) Mountain, and (9) Pacific. ${ }^{1}$

The first two columns of numerical values in Table 1 give each state's Brady Score in 2011 and 2013 [1, 2]. For each year, 36 (i.e., the number of combinations of nine census divisions taken two at a time) different two-sample $t$-tests will be run comparing the average Brady Score of one census division to that of another.

Nine additional paired $t$-tests will compare each census division's average Brady Score in 2011 with its respective average two years later. For example, in the New England census division, the 2011 score for Connecticut is matched with the 2013 score for Connecticut; the 2011 score for Vermont is matched with the 2013 score for Vermont, and so forth for the remaining states in New England.

Finally, we will examine the effects of firearm death rates, the party in control of the state's legislature, and regional factors on the Brady Scores. This will be done by means of regressions fitted to the cross-section of all states ${ }^{2}$ in each year (2011 and 2013) of the following form:

BradyScore $=\mathrm{b}_{0}+\mathrm{b}_{1}$ Firearm $+\mathrm{b}_{2}$ PartyControl $+\sum_{i=1}^{9} c_{i} R_{i}$ where BradyScore is the state's Brady Score; Firearm is the state's number of deaths due to injury by firearms per 100,000 population [3]; PartyControl, a binary variable, is equal to 1 if the state's House and Senate were controlled by the Democrats, and 0 otherwise $[4,5]$; and the $R_{i}$ are nine dummy variables employed to capture the regional pattern of Brady Scores that emerges after the firearm death rate and legislative party control variables (hereafter referred to as the core variables) have been taken into account. The regressions (one each for 2011 and 2013) will show differences in average Brady Scores after allowing for differences across states in the core variables and should not therefore correspond to the results of the first set of two-sample $t$-tests. If they did, it would imply that the core variables had no influence at all on Brady Scores.

\section{Results}

The results of all 36 two-tailed $t$-tests between census divisions are compactly summarized in Tables 2 and 3 for the years 2011 and 2013, respectively. "Higher" ("Lower") in either table indicates that the average Brady Score of states in the census division listed along the bottom edge of the table was significantly higher (lower) than the average Brady Score of states in the census division listed along the vertical lefthand edge of the table. Results in boldface are significant at the .05 level while italicized results are significant at the .10 level.

Table 2 shows that in 2011 the average Brady Score of states in the Pacific census division was significantly higher than the average Brady Score of states in five other census divisions. Average Brady Scores were higher (lower) in Middle Atlantic (Mountain) states and New England (West North Central) states compared to states in three (four) other census divisions.

Table 3 shows 2013 results that are similar to those for 2011. States with discernibly higher (lower) average Brady Scores belong to the Pacific, Middle Atlantic, and New England (Mountain and West North Central) census divisions. Brady Scores were, on average, higher in 2013 in the East North Central census division compared to the West South Central and East South Central census divisions than they were in 2011. In four instances, discernable differences between two census divisions in 2011 had disappeared two years later. For example, in 2011 New England's (West North Central's) average Brady Score was higher (lower) than South Atlantic's average Brady Score. Two years later, there 
were no discernible differences between these census divisions. Either Brady Scores had, on average, decreased in
New England states or they had increased in South Atlantic states.

Table 1: Brady Scores, Party Control, Firearm Death Rate by State and Year

\begin{tabular}{|c|c|c|c|c|c|}
\hline \multirow[t]{2}{*}{ State } & \multicolumn{2}{|c|}{ Brady Scores } & \multicolumn{2}{|c|}{$\begin{array}{c}\begin{array}{c}\text { Party Control } \\
\text { of }\end{array} \\
\text { State Legislature } \\
\end{array}$} & \multirow{2}{*}{$\begin{array}{c}\text { Firearm Death Rate } \\
2010\end{array}$} \\
\hline & 2011 & 2013 & 2011 & 2013 & \\
\hline Alabama & 14 & 3.5 & $\mathrm{R}$ & $\mathrm{R}$ & 16.2 \\
\hline Alaska & 0 & -7 & Split & $\mathrm{R}$ & 20.4 \\
\hline Arizona & 0 & -8 & $\mathrm{R}$ & $\mathrm{R}$ & 14.6 \\
\hline Arkansas & 4 & 1 & $\mathrm{D}$ & $\mathrm{R}$ & 14.4 \\
\hline California & 81 & 75 & $\mathrm{D}$ & $\mathrm{D}$ & 7.7 \\
\hline Colorado & 15 & 14.5 & Split & $\mathrm{D}$ & 10.8 \\
\hline Connecticut & 58 & 70 & $\mathrm{D}$ & $\mathrm{D}$ & 5.9 \\
\hline Delaware & 13 & 34.5 & $\mathrm{D}$ & $\mathrm{D}$ & 9.9 \\
\hline Florida & 3 & 3 & $\mathrm{R}$ & $\mathrm{R}$ & 11.5 \\
\hline Georgia & 8 & 2 & $\mathrm{R}$ & $\mathrm{R}$ & 12.6 \\
\hline Hawaii & 50 & 58.5 & $\mathrm{D}$ & $\mathrm{D}$ & 3.2 \\
\hline Idaho & 2 & 0 & $\mathrm{R}$ & $\mathrm{R}$ & 12.8 \\
\hline Illinois & 35 & 45 & $\mathrm{D}$ & $\mathrm{D}$ & 8.2 \\
\hline Indiana & 4 & 4.5 & $\mathrm{R}$ & $\mathrm{R}$ & 10.8 \\
\hline Iowa & 7 & 14 & Split & Split & 6.8 \\
\hline Kansas & 4 & -4 & $\mathrm{R}$ & $\mathrm{R}$ & 10.5 \\
\hline Kentucky & 2 & -3.5 & Split & Split & 12.4 \\
\hline Louisiana & 2 & -2 & $\mathrm{R}$ & $\mathrm{R}$ & 19.2 \\
\hline Maine & 7 & 3 & $\mathrm{R}$ & $\mathrm{D}$ & 7.9 \\
\hline Maryland & 45 & 66.5 & $\mathrm{D}$ & $\mathrm{D}$ & 9.3 \\
\hline Massachusetts & 65 & 60.5 & $\mathrm{D}$ & $\mathrm{D}$ & 4.1 \\
\hline Michigan & 25 & 15 & $\mathrm{R}$ & $\mathrm{R}$ & 11 \\
\hline Minnesota & 14 & 19.5 & Split & $\mathrm{D}$ & 6.8 \\
\hline Mississippi & 4 & -4 & $\mathrm{R}$ & $\mathrm{R}$ & 16.1 \\
\hline Missouri & 4 & -0.5 & $\mathrm{R}$ & $\mathrm{R}$ & 14 \\
\hline Montana & 2 & -3 & $\mathrm{R}$ & $\mathrm{R}$ & 15.4 \\
\hline Nebraska $^{1}$ & 5 & 6.5 & N/A & N/A & 8.2 \\
\hline Nevada & 5 & 1.5 & $\mathrm{D}$ & $\mathrm{D}$ & 14.5 \\
\hline New Hampshire & 6 & 5.5 & $\mathrm{R}$ & Split & 8.2 \\
\hline New Jersey & 72 & 68.5 & $\mathrm{D}$ & $\mathrm{D}$ & 5.2 \\
\hline New Mexico & 4 & 0 & $\mathrm{D}$ & $\mathrm{D}$ & 14.9 \\
\hline New York & 62 & 65.5 & Split & $\mathrm{D}$ & 5.1 \\
\hline North Carolina & 16 & 1.5 & $\mathrm{R}$ & $\mathrm{R}$ & 11.6 \\
\hline North Dakota & 2 & 2 & $\mathrm{R}$ & $\mathrm{R}$ & 9.5 \\
\hline Ohio & 7 & 10 & $\mathrm{R}$ & $\mathrm{R}$ & 9.9 \\
\hline Oklahoma & 2 & 1 & $\mathrm{R}$ & $\mathrm{R}$ & 14.4 \\
\hline Oregon & 15 & 11 & Split & $\mathrm{D}$ & 11.4 \\
\hline Pennsylvania & 26 & 20 & $\mathrm{R}$ & $\mathrm{R}$ & 10.1 \\
\hline Rhode Island & 44 & 41.5 & $\mathrm{D}$ & $\mathrm{D}$ & 4.6 \\
\hline South Carolina & 8 & 1 & $\mathrm{R}$ & $\mathrm{R}$ & 14 \\
\hline South Dakota & 4 & -4.5 & $\mathrm{R}$ & $\mathrm{R}$ & 9.2 \\
\hline Tennessee & 8 & 2 & $\mathrm{R}$ & $\mathrm{R}$ & 14.4 \\
\hline Texas & 4 & 1.5 & $\mathrm{R}$ & $\mathrm{R}$ & 11 \\
\hline Utah & 0 & -2 & $\mathrm{R}$ & $\mathrm{R}$ & 12.2 \\
\hline Vermont & 6 & -4 & $\mathrm{D}$ & $\mathrm{D}$ & 10.3 \\
\hline Virginia & 12 & 7 & Split & $\mathrm{R}$ & 10.8 \\
\hline Washington & 15 & 19.5 & $\mathrm{D}$ & $\mathrm{D}$ & 8.9 \\
\hline West Virginia & 4 & 3 & $\mathrm{D}$ & $\mathrm{D}$ & 14.1 \\
\hline Wisconsin & 3 & 13 & $\mathrm{R}$ & $\mathrm{R}$ & 8.6 \\
\hline Wyoming & 4 & -5 & $\mathrm{R}$ & $\mathrm{R}$ & 15.6 \\
\hline
\end{tabular}

${ }^{\mathbf{1}}$ Nebraska has a unicameral, non-partisan legislature. 
Table 2: Summary of Two-Sample $t$-Tests, 2011

\begin{tabular}{|c|c|c|c|c|c|c|c|c|}
\hline Mountain & Higher $^{1}$ & & & & & & & \\
\hline West North Central & Higher & No & & & & & & \\
\hline East North Central & No & Lower $^{3}$ & Lower ${ }^{4}$ & & & & & \\
\hline Middle Atlantic & No & Lower & Lower & Lower & & & & \\
\hline New England & No & Lower & Lower & No & No & & & \\
\hline South Atlantic & Higher $^{2}$ & Lower & Lower & No & Higher & Higher & & \\
\hline East South Central & Higher & No & No & No & Higher & Higher & No & \\
\hline \multirow[t]{2}{*}{ West South Central } & Higher & No & No & No & Higher & Higher & Higher & Higher \\
\hline & Pacific & Mountain & $\begin{array}{l}\text { West North } \\
\text { Central }\end{array}$ & $\begin{array}{c}\text { East } \\
\text { North } \\
\text { Central }\end{array}$ & $\begin{array}{l}\text { Middle } \\
\text { Atlantic }\end{array}$ & $\begin{array}{c}\text { New } \\
\text { England }\end{array}$ & $\begin{array}{c}\text { South } \\
\text { Atlantic }\end{array}$ & $\begin{array}{c}\text { East } \\
\text { South } \\
\text { Central }\end{array}$ \\
\hline
\end{tabular}

\footnotetext{
${ }^{1}$ A bolded Higher in the table indicates that the census division listed along the bottom of the table had a significantly higher average Brady Score (at the .05 level) than the census division listed along the left-hand edge of the table. For example, the Pacific census division had a higher average Brady Score than the Mountain census division.

${ }^{2}$ An italicized Higher in the table indicates that the census division listed along the bottom of the table had a significantly higher average Brady Score (at the .10 level) than the census division listed along the left-hand edge of the table.

${ }^{3}$ A bolded Lower in the table indicates that the census division listed along the bottom of the table had a significantly lower average Brady Score (at the .05 level) than the census division listed along the left-hand edge of the table.

${ }^{4}$ An italicized Lower in the table indicates that the census division listed along the bottom of the table had a significantly lower average Brady Score (at the .10 level) than the census division listed along the left-hand edge of the table.
} 
Table 3: Summary of Two-Sample $t$-Tests, 2013

\begin{tabular}{|c|c|c|c|c|c|c|c|c|}
\hline Mountain & Higher $^{1}$ & & & & & & & \\
\hline West North Central & Higher & No & & & & & & \\
\hline East North Central & No & Lower $^{3}$ & Lower & & & & & \\
\hline Middle Atlantic & No & Lower & Lower & Lower & & & & \\
\hline New England & No & Lower & Lower & No & No & & & \\
\hline South Atlantic & Higher $^{2}$ & Lower ${ }^{4}$ & No & No & Higher & No & & \\
\hline East South Central & Higher & No & No & Higher & Higher & Higher & No & \\
\hline \multirow[t]{2}{*}{ West South Central } & Higher & No & No & Higher & Higher & Higher & No & No \\
\hline & Pacific & Mountain & $\begin{array}{l}\text { West North } \\
\text { Central }\end{array}$ & $\begin{array}{c}\text { East } \\
\text { North } \\
\text { Central }\end{array}$ & $\begin{array}{l}\text { Middle } \\
\text { Atlantic }\end{array}$ & $\begin{array}{c}\text { New } \\
\text { England }\end{array}$ & $\begin{array}{c}\text { South } \\
\text { Atlantic }\end{array}$ & $\begin{array}{c}\text { East } \\
\text { South } \\
\text { Central }\end{array}$ \\
\hline
\end{tabular}

\footnotetext{
${ }^{1}$ A bolded Higher in the table indicates that the census division listed along the bottom of the table had a significantly higher average Brady Score (at the .05 level) than the census division listed along the left-hand edge of the table. For example, the Pacific census division had a higher average Brady Score than the Mountain census division.

${ }^{2}$ An italicized Higher in the table indicates that the census division listed along the bottom of the table had a significantly higher average Brady Score (at the .10 level) than the census division listed along the left-hand edge of the table.

${ }^{3}$ A bolded Lower in the table indicates that the census division listed along the bottom of the table had a significantly lower average Brady Score (at the .05 level) than the census division listed along the left-hand edge of the table.

${ }^{4}$ An italicized Lower in the table indicates that the census division listed along the bottom of the table had a significantly lower average Brady Score (at the .10 level) than the census division listed along the left-hand edge of the table.
} 
Table 4 summarizes the results of the paired comparisons in 2011 and 2013 between states in a given census division. In not one single census division did gun laws between 2011 and 2013 become significantly more restrictive. Yet, in states in three different census divisions (Mountain, West South Central, and East South Central), gun laws actually became less restrictive.

Table 4: Average Brady Scores by Census Division and Year

\begin{tabular}{|c|c|c|c|}
\hline \multirow{2}{*}{ Census Division } & \multicolumn{2}{|c|}{ Average Brady Scores } & \multirow{2}{*}{$\begin{array}{l}p \text {-Value on } \\
\text { difference }^{1}\end{array}$} \\
\hline & 2011 & 2013 & \\
\hline Pacific & 32.20 & 31.40 & 0.808 \\
\hline Mountain & 4.00 & -0.25 & 0.005 \\
\hline $\begin{array}{l}\text { West North } \\
\text { Central }\end{array}$ & 5.71 & 4.71 & 0.685 \\
\hline $\begin{array}{l}\text { West South } \\
\text { Central }\end{array}$ & 3.00 & 0.375 & 0.025 \\
\hline East North Central & 14.80 & 17.50 & 0.505 \\
\hline East South Central & 7.00 & -0.50 & 0.007 \\
\hline Middle Atlantic & 53.33 & 51.33 & 0.555 \\
\hline $\begin{array}{c}\text { South } \\
\text { Atlantic }\end{array}$ & 13.63 & 14.83 & 0.808 \\
\hline New England & 31.00 & 29.42 & 0.621 \\
\hline
\end{tabular}

${ }^{1}$ All p-values are for a two-tailed test.

To permit measurement of variations in the roles played by individual census divisions, the set of nine dummy variables $R_{i}$ was introduced, and the regression results are summarized in Table 5. These results show that when Democrats control the state legislature, Brady Scores tend to be higher. When firearm death rates (per 100,000 residents) are higher, Brady Scores tend to be lower. Alaska, the state with the highest firearm death rate, had a Brady Score of zero in 2011 and -7 in 2013. By contrast, Hawaii and Massachusetts, the states with the lowest firearm death rates, had Brady Scores of 50 and 65, respectively, in 2011; 58.5 and 60.5 , respectively, in 2013. Both core variables are statistically significant $(\alpha=.01)$ in both years. 
Table 5: Regression of Brady Campaign Scores on Core Variables (A) Including and (B) Excluding Census Division Dummies

\section{Regression Coefficient on}

\begin{tabular}{llcl}
\hline Constant & $\begin{array}{l}\text { Party control of } \\
\text { state legislature }\end{array}$ & $\begin{array}{c}\text { Firearm } \\
\text { death rate }\end{array}$ & $\mathbf{R}^{2}$
\end{tabular}

2011

\begin{tabular}{lllll}
\hline (A) & $\begin{array}{l}41.203 \\
(4.80)^{1}\end{array}$ & $\begin{array}{c}13.736 \\
(2.88)\end{array}$ & $\begin{array}{r}-2.833 \\
(-3.82)\end{array}$ & 0.709 \\
& & & & \\
\hline & & & & \\
(B) & 44.926 & $(3.32)$ & -3.035 & 0.558 \\
& $(6.10)$ & & $(-5.22)$ & \\
\hline
\end{tabular}

2013

\begin{tabular}{|c|c|c|c|c|}
\hline (A) & $\begin{array}{c}40.564 \\
(3.82)\end{array}$ & $\begin{array}{l}16.992 \\
(3.02)\end{array}$ & $\begin{array}{l}-3.703 \\
(-4.35)\end{array}$ & 0.733 \\
\hline (B) & $\begin{array}{c}44.085 \\
(5.02)\end{array}$ & $\begin{array}{l}18.823 \\
(3.67)\end{array}$ & $\begin{array}{l}-3.328 \\
(-5.03)\end{array}$ & 0.634 \\
\hline
\end{tabular}

${ }^{1}$ Figures in parentheses are t-values.

In fitting the regression equations, the average of the coefficients of the $R_{i}$ dummy variables was constrained to zero [6]. As a result, positive coefficients on dummy variables in Table 6 correspond to census divisions whose Brady Scores were above average, and negative coefficients correspond to census divisions whose Brady Scores were below average after statewide differences in the core variables have been allowed for.

The contribution of the regional pattern to the regression analysis can be measured by a partial $R^{2}$, calculated by comparing the total $R^{2}$ of the final regression [regression (A) in Table 5] to that of the same regression with the dummy variables omitted [regression (B) in Table 5]. If $R_{1}^{2}$ is the (unadjusted) total $\mathrm{R}^{2}$ when the dummy variables are omitted and $R_{2}^{2}$ is the total $R^{2}$ including the dummy variables, then the partial $R^{2}$ contributed by the dummies is equal to

$$
\left(R_{2}^{2}-R_{1}^{2}\right) /\left(1-R_{1}^{2}\right) \text {. }
$$

This can be subject to an $\mathrm{F}$ test for significance in the usual way.
Table 6 shows the regional effects, $R_{i}$, which summarize the effect of the peculiarities of individual census divisions vis-à-vis other census divisions. The contribution made by the regional dummy variables was significantly different from zero in $2011(p=.029)$, but marginally not significant two years later $(p=.116)$. A definite regional pattern nonetheless emerges.

The peculiarities of certain census divisions are clearly marked. Note, for example, the extraordinarily high Brady Scores in the Middle Atlantic States (New Jersey, New York, and Pennsylvania) and the Pacific states (within which there is substantial variation, but the notable high scores are in California and Hawaii). Taking an overview of various coefficients on the $R_{i}$, it is clear that in most cases census divisions with above (below) average Brady Scores in 2011 had above (below) average Brady Scores in 2013. In two census divisions - South Atlantic and West South Central Brady Scores were below average in 2011, but above average two years later. Table 6 suggests that in 2013, after core variables are allowed for, the Middle Atlantic States have the highest Brady Scores and West North Central states as well as, surprisingly, New England states have the lowest. 
Table 6: Regional Effects: Coefficients of $R_{i}$

2011

8.050

$\mathbf{R}_{1}$ : Pacific

\begin{tabular}{|c|c|c|}
\hline & 2011 & 2013 \\
\hline $\mathbf{R}_{1}:$ Pacific & 8.050 & 5.559 \\
\hline $\mathbf{R}_{2}:$ Mountain & -5.341 & -5.796 \\
\hline $\mathbf{R}_{3}:$ West North Central & -12.493 & -13.823 \\
\hline $\mathbf{R}_{4}$ : East North Central & -5.612 & -0.442 \\
\hline $\mathbf{R}_{6}$ : Middle Atlantic & 22.873 & 14.722 \\
\hline $\mathbf{R}_{6}$ : South Atlantic & -3.454 & 1.397 \\
\hline $\mathbf{R}_{7}$ : East South Central & 3.714 & 3.752 \\
\hline $\mathbf{R}_{8}:$ West South Central & -3.791 & 4.534 \\
\hline $\mathbf{R}_{9}$ : New England & -3.945 & -9.903 \\
\hline Partial $\mathbf{R}^{2}$ contributed by region: & $.343^{1}$ & $.270^{2}$ \\
\hline
\end{tabular}

${ }^{1}$ F-test is significant at the .05 level with 8,38 degrees of freedom.

2013

5.559

\footnotetext{
${ }^{2} \mathrm{~F}$-test is not significant at the .05 level with 8,38 degrees of freedom.
}

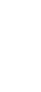

Table 6: Regional Effects: Coefficients of $R_{i}$

\section{Concluding Remarks}

Three factors alone - firearm death rates, legislative partisan composition, and regional differences - explain better than two-thirds of the variation in Brady Scores in 2011 and 2013.

The statistics presented in this paper show that in the year after the shooting in Newtown, Connecticut, gun laws have either not changed or in census divisions where they have significantly changed, they have become less restrictive (as measured by a state's Brady Score). Even in New England states, after allowing for differences in legislative partisan composition and firearm death rates, gun laws appear less restrictive vis-à-vis states in other census divisions in 2013 when compared to a year before the shooting in Newtown. 


\section{References}

1. 2011 Brady Campaign State Scorecard. The Brady Campaign to Prevent Gun Violence, 2011. www.bradycampaign.org/sites/default/files/2011\%20Fin al\%20state20scoresA3-2\%20Sheet1.pdf.

2. 2013 Brady Campaign State Scorecard. The Brady Campaign to Prevent Gun Violence, 2013. www.bradycampaign.org/2013-state-scorecard .

3. Number of deaths due to injury by firearm per 100,000 population. The Henry J. Kaiser Family Foundation, 2014. http://kff.org/other/state-indicator/firearms-deathrate-per-100000/

4. 2011 Post-Election State and Legislative Partisan Composition, National Conference of State Legislatures, December 14, 2011.

www.ncsl.org/documents/statevote/2011_Legis_and_Sta te_post.pdf

5. 2013 Post-Election State and Legislative Partisan Composition, National Conference of State Legislatures, November 6, 2013.

www.ncsl.org/documents/StateVote/2013 Legis and sta te_Nov6.pdf

6. D. B. Suits, Use of dummy variables in regression equations, Journal of the American Statistical Association, vol. 52, 548-551, December 1957.

\section{Footnotes}

1. The nine divisional groupings and their constituent states are: (1) New England: Connecticut, Maine, Massachusetts, New Hampshire, Rhode Island, Vermont; (2) Middle Atlantic: New Jersey, New York, Pennsylvania; (3) East North Central: Indiana, Illinois, Michigan, Ohio, Wisconsin; (4) West North Central: Iowa, Kansas, Minnesota, Missouri, Nebraska, North Dakota, South Dakota; (5) South Atlantic: Delaware, Florida, Georgia, Maryland, North Carolina, South Carolina, Virginia, West Virginia; (6) East South Central: Alabama, Kentucky, Mississippi, Tennessee; (7) West South Central: Arkansas, Louisiana, Oklahoma, Texas; (8) Mountain: Arizona, Colorado, Idaho, New Mexico, Montana, Utah, Nevada, Wyoming; and (9) Pacific: Alaska, California, Hawaii, Oregon, Washington. (www.census.gov/geo/maps_data/maps/docs/reg_div.txt).

2. Nebraska's state legislature is unicameral and is therefore excluded from our sample. 